\title{
Serum Ferritin Level in Preterm Labour
}

\author{
AYESHA SIDDIKA ${ }^{1}$, BEGUM NASRIN ${ }^{2}$, SHAYELA SHAMIM ${ }^{3}$, NURJAHAN BEGUM ${ }^{4}$, \\ N NAHAR ${ }^{5}$, SULTANA RAZIA BEGUM ${ }^{6}$
}

\begin{abstract}
Objective: The aim of this study was to investigate causal association of serum ferritin with pre-term labour. Materials and Methods: This is a case-control study done on one hundred and twenty women from July 2005 to June 2007 in the department of obstetrics and gynecology of Bangabandhu Sheikh Mujib Medical University (BSMMU) and Mother and Child Health Training Institute (MCHTI), Azimpur, Dhaka. Cases $(n=60)$ were singleton pregnant women starting preterm labour within 28-36 weeks of pregnancy and control $(n=60)$ were singleton pregnant women of $>37$ weeks of gestation who were in lalour. In this case-control study pre-term labour patients were compared with controls regarding their serum ferritin level. Result: Mean $\pm S D$ serum ferritin level of control and in pre-term labour group of women were $37.01 \pm 26.84 \mu \mathrm{g} / \mathrm{L}$ was $210.37 \pm 67.20 \mu \mathrm{g} / \mathrm{L}$ respectively. The difference between two groups was statistically highly significant $(<0.001)$
\end{abstract}

Key words: Preterm lalour, serum ferritin

\section{Introduction}

Preterm labour complicates 8 to 10 percent of all pregnancies and is the leading cause of perinatal morbidity and mortality ${ }^{1}$. In 65 percent cases of preterm birth, there is always a predisposing cause, however, in 35 percent cases of preterm birth, there is no obvious aetiology ${ }^{2}$. Although the pathophysiology of preterm labour remains incompletely defined, a growing body of evidence is emerging that links occult upper genital tract infection with subsequent spontaneous preterm labour ${ }^{3}$. Recently, in asymptomatic women, several serum (G CSF and ferritin) and cervicovaginal (fetal fibronectin, interleukin 6 and lactoferrin) inflammatory markers have been shown to be potent predictors of spontaneous preterm delivery in otherwise asymptomatic women ${ }^{4}$. One particularly interesting potential marker is ferritin. Ferritin is an iron storage protein synthesized by a variety of tissues primarily the liver, spleen, bone and placenta. It is also released by infiltrating leukocytes, in response to acute and chronic infection. Several previous investigations have indicated an association between elevated serum ferritin concentration and preterm delivery ${ }^{5}$. The present study was designed to explore the role of serum ferritin as a possible marker of infection, associated with pre-term labour.

\section{Materials and Methods}

This case control study was carried out in the Department of Obstetrics and Gynaecology, Bangabandhu Sheikh Mujib Medical University (BSMMU) and Mother and Child Health Training Institute (MCHTI), Azimpur, Dhaka during the period from July 2005 to June 2007 . The aim of this study was to explore whether there is any causal association between maternal serum ferritin level and preterm labour. A total one hundred twenty pregnant women attending in patient department of Obstetrics and Gynaecology, BSMMU and MCHTI, were selected for the study. Among them 60 women were selected as cases and 60 as controls. Cases were singleton pregnant women of 28-36 weeks of pregnancy starting preterm labour and control were singleton pregnant

1. Consultant, Obstetrics and Gynaecology, Kapasia THC

2. Associate Professor, Department of Obstetrics and Gynaecology, BSMMU, Dhaka

3. Associate Professor, Department of Obstetrics and Gynaecology, BSMMU, Dhaka

4. Consultant, Obstetrics and Gynaecology, BSMMU, Dhaka

5. Assistant Professor, Department of Obstetrics and Gynaecology, BSMMU, Dhaka

6. Department of Obstetrics and Gynaecology, BSMMU, Dhaka 
women of $>37$ weeks of gestation who were in lalour. Purposive consecutive sampling technique was applied to enrol study subjects for this study. To confirm whether the patients were actually in labour or not regular uterine contraction documented by uterine palpation, generally more than two in 30 minutes and dilatation and effacement of cervix were assessed. Subject having anaemia $(\mathrm{Hb}<10 \mathrm{~g} / \mathrm{dl})$, preexisting chronic infectious diseases, multiple pregnancy, polyhydramnios, diabetes mellitus, preeclampsia or eclampsia were excluded from the study. Women having liver disease, renal disease, history of sexual intercourse within last 72 hours or having any fetal congenital anomaly were also excluded.

When criteria of our study were fulfilled the purpose of the study was explained to the pregnant mother and only those who agreed were finally selected for the study. An informed written consent was taken from each respondent. Ethical clearance for the study was taken from the Central Ethical Committee, BSMMU. Permission for the study was also taken from the concerned departments from where study subjects were collected.

All the variables of interest were collected by detailed history, clinical examination and biochemical investigations and recorded in the pre designed data collection sheet. All information was kept confidential. From each subject, $5 \mathrm{ml}$ blood was taken for analysis of serum ferritin.

Maternal serum ferritin was assessed by AxSYM Ferritin, a Microparticle Enzyme Immunoassay (MEIA).
All relevant data for each individual study subjects were collected and recorded in a pre designed data collection sheet. Comparisons between groups were done using unpaired Student's 't' test, $p$ value of $<0.05$ was considered as significant. All the statistical analysis was done with the statistical package for social science (SPSS).

\section{Result}

Total 120 patients were enrolled in this study; among them 60 were cases and 60 controls. The two groups were matched with each other in term of age, parity, and socioeconomic status (Table I). Mean \pm SD age of control and case group of women were $24.26 \pm 3.6$ and $26.35 \pm 4.6$ years respectively. Twenty eight (46.7\%) women of control group and 22 (36.7\%) of case group were nulliparous. In control group 32 (53.3\%) and in case group 38 (63.3\%) women were multiparous. Most of the study subjects, both control and case groups, belonged to middle socioeconomic status (86.7 and $66.7 \%)$. Mean $\pm S D$, gestational age of control and case group of women were $39.23 \pm 0.77$ and $34.6 \pm 0.97$, weeks respectively (Table I). Packed cell volume (PCV) levels, mean $\pm S D$, of control and case group of women were $37.8 \pm 1.2$ and $37.9 \pm 1.4 \%$, respectively and difference $(p>0.5)$ was not statistically significant (Table II). There was no significant difference in, mean $\pm S D$, total iron binding capacity (TIBC) between control and case groups (303.33 \pm 4.10 vs $305.43 \pm 7.16 \mathrm{ig} / \mathrm{dl}$; $\mathrm{p}=0.10)$. The mean $\pm S D$ serum ferritin level in control and case group were $37.01 \pm 26.84 \mu \mathrm{g} / \mathrm{L}$ $210.37 \pm 67.20 \mu \mathrm{g} / \mathrm{L}$ respectively and the difference was statistically highly significant $(p<.001)$.

Table - I

Socio-demographic characteristics of the study subjects

\begin{tabular}{lccc}
\hline Characteristics & Control $(\mathrm{n}=60)$ & Case $(\mathrm{n}=60)$ & $\mathrm{p}$-value \\
\hline Age (years) & $24.26 \pm 3.60$ & $26.35 \pm 4.56$ & $\mathrm{NS}$ \\
Parity & & & $\mathrm{NS}$ \\
Nulipara & $28(46.7)$ & $22(36.6)$ & $\mathrm{NS}$ \\
Multipara & $32(53.3)$ & $38(63.3)$ & $\mathrm{NS}$ \\
Socio-economic status & & & $\mathrm{NS}$ \\
Low & $8(13.3)$ & $20(33.3)$ & $<0.001^{\text {** }}$ \\
Middle & $52(86.7)$ & $40(66.7)$ & $34.60 \pm 0.97$ \\
Gestational age (weeks) & $39.23 \pm 0.77$ & &
\end{tabular}

Results are expressed as mean $\pm S D ; n=$ number of subjects; unpaired Student's 't' test was done as test of significance; NS = Not significant; ${ }^{* \star *}=$ significant; percentage is within parenthesis 
Table-II

PCV level between control and case groups

\begin{tabular}{lccc}
\hline PCV $(\%)$ & Control $(\mathrm{n}=60)$ & Case $(\mathrm{n}=60)$ & $\mathrm{p}$ - value \\
\hline Mean \pm SD & $37.80 \pm 1.16$ & $37.88 \pm 1.42$ & $>0.5^{\mathrm{ns}}$ \\
Range & $36-40$ & $35-40$ & \\
\hline
\end{tabular}

$P C V=$ packed cell volume; $n=$ number of subjects; unpaired ' $t$ ' test was done as test of significance; ns = not significant

Table-III

TIBC level between control and case groups

\begin{tabular}{lccc}
\hline TIBC $(\mu \mathrm{g} / \mathrm{dll})$ & Control $(\mathrm{n}=60)$ & Case $(\mathrm{n}=60)$ & $\mathrm{p}$ - value \\
\hline Mean \pm SD & $303.33 \pm 4.10$ & $305.43 \pm 7.16$ & $0.10^{\text {ns }}$ \\
Range & $300-310$ & $300-325$ & \\
\hline
\end{tabular}

TIBC= total iron binding capacity; $n=$ number of subjects; unpaired Student's ' $\mathrm{t}$ ' test was done as test of significance; $n s=$ not significant

Table-IV

Serum ferritin level between control and case groups

\begin{tabular}{lccc}
\hline Serum ferritin $(\mu \mathrm{g} / \mathrm{L})$ & Control $(\mathrm{n}=60)$ & Case $(\mathrm{n}=60)$ & $\mathrm{p}$ - value \\
\hline Mean \pm SD & $37.01 \pm 26.84$ & $210.37 \pm 67.20$ & $<0.001^{\star \star *}$ \\
Range & $8.15-80.99$ & $111.15-342.58$ & \\
\hline
\end{tabular}

$\mathrm{n}=$ number of subjects; unpaired Student's 't' test done was as test of significance;

$\star \star \star ~=~ S i g n i f i c a n t$

\section{Discussion}

The findings of the present study demonstrated that serum ferritin level was higher in preterm labour. The normal range of serum ferritin level in adult female is $22-120 \mu \mathrm{g} / \mathrm{L}$. The difference in serum ferritin levels between the study and control groups was statistically highly significant $(P<0.001)$. Serum ferritin level in the control group was $37.01 \pm 26.8 \mu \mathrm{g} / \mathrm{L}$ and in the case was $210.37 \pm 67.20 \mu \mathrm{g} / \mathrm{L}$.

Paternoster et al reported no significant influence of age or parity on serum ferritin level in preterm labour. However, they observed significant influence of socioeconomic status on serum ferritin level and preterm labour ${ }^{6}$. In the present study, no significant difference in age, parity and socioeconomic status between control and case groups were observed. Saha et al reported that mean serum ferritin levels in patients with preterm labour was $23.26 \pm 14.13 \mathrm{ng} / \mathrm{ml}$ and in term labour was $8.69 \pm 3.7 \mathrm{ng} / \mathrm{ml}^{7}$. According to Scholl et al, serum ferritin of preterm labour was $23.24 \pm 12.13 \mathrm{ng} /$ $\mathrm{ml}^{8}$. The findings of these studies do not correlate with the result of our study. In two other studies, the serum ferritin level in preterm labour was $89.0 \pm 31.1 \mathrm{ng} /$ $\mathrm{ml}$ and $43.2 \pm 35.9 \mathrm{ng} / \mathrm{ml}$ respectively ${ }^{9,10}$. In our study, serum ferritin level was higher than other studies. The present study was planned to assay the serum ferritin levels in women with preterm labour. The purpose of this analysis was to explore whether serum ferritin levels which may be raised in any infective process could be used as a marker of preterm labour. Preterm delivery is commonly associated with anaemia and poor maternal weight gain during pregnancy. It was found that the relationship between anaemia and preterm delivery was specific to iron deficiency anaemia and the risk was more than double ${ }^{8}$. Anaemia during the second trimester has also been shown to be positively associated with spontaneous preterm birth although anaemia later in pregnancy was negatively associated with preterm birth ${ }^{11}$. In the present study, there was no significant difference in the mean $\pm S D$ PCV and TIBC values between control and case groups of women (PCV, 37.8 \pm 1.2 vs $37.88 \pm 1.4 \%$, and TIBC $303.33 \pm 4.1$ vs $305.43 \pm 7.2 \mathrm{ig} /$ dl). Similar study by Saha et al also reported that there was no significant difference in PCV and TIBC between term and preterm labour ${ }^{7}$. Alteration of plasma ferritin level can lead to adverse pregnancy outcomes. Increasing pathophysiological evidence is emerging that there is link of lower and upper genital tract infection with early spontaneous preterm 
delivery ${ }^{12,13}$. Although treatment of lower genital tract infection (bacterial vaginosis) has been shown to reduce the occurrence of spontaneous preterm delivery in some high risk population, it is unclear whether such infections are causal or merely associated with a concurrent occult chronic upper genital tract infection. However, in two small, randomized trials, a prolonged course of metronidazole plus ampicillin resulted in a substantial delay in delivery, a reduction in the incidence of preterm delivery and lower neonatal morbidity, as compared with placebo ${ }^{14}$. In practice, pregnant women with asymptomatic upper genital tract infection are not routinely screened or treated. Thus, the high serum ferritin level in the study group is most likely a part of acute phase reaction to a subclinical infection. Its treatment could have a substantial effect on the incidence of preterm delivery of infants with low birth weight. These findings are consistent with earlier studies $8,14,15$. High serum ferritin levels in apparently healthy pregnant women may help one to anticipate delivery and to take appropriate action. Above mentioned research findings demonstrated significant correlation between elevated serum ferritin and preterm delivery.

\section{Conclusion}

From the present study it may be concluded that serum ferritin level may be considered as an important parameter for detecting preterm labour. In the cases of high level of serum ferritin, treatment may be instituted to prevent preterm birth. The result of the study adds to the existing evidence that high serum ferritin level is a risk factor for preterm birth. So, timely detection and intervention could easily prevent high serum ferritin related adverse pregnancy outcome.

\section{References}

1. Dutta DC. 1998. Textbook of obstetrics. 6th ed. Calcutta: New Central Book Agency (P) Ltd., pp. 324-35.

2. Arias F, Tomich P. 1982. Etiology and outcome of low birth and preterm infants. Obstet Gynaecol 60:277.

3. Leonardo CHB, Cresfor SAA, James SA, Siegel E, Wilcon S. 1990. Work related physical excretion and risk of preterm low birth weight delivery. Pediatr Perinat Epidemiol 4: 161-74.

4. Pushpo D, Jagdish WMA. 1991. A study of serum ferritin level in preterm labour. $\mathrm{J}$ Obstet Gynaecol India 41: 269-73.
5. Risk WM. 1992. Serum ferritin and prevention of preterm labour in high risk group of patients. Am J Obstet Gynecol 166:144-7.

6. Paternoster DM, Stella A, Gerace P, Manganelli F, Plebani M, Snijders D, et al. 2002. Biochemical markers for the prediction of spontaneous preterm birth. Int J Gynecol Obstet 79: 123-9.

7. Saha CK, Jain V, Gupta I, Varma N. 2000. Serum ferritin level as a marker of preterm labor. Int J Gynecol Obstet 71: 107-11.

8. Scholl TO, Hediger ML, Fischer RL, Shearer JW. 1992. Anemia vs iron deficiency: increased risk of preterm delivery in a prospective study. $A m \mathrm{~J}$ Clin Nutr 55: 985-8.

9. Goldenberg RL, Hauth JC, Andrews RL. 1998. Infection related risk factors predictive of spontaneous preterm labor and birth. Prenatal Neonatal Med 3: 86-90.

10. Ramsey PS, Tamura T, Goldenberg RL, Mercer BM, lams JD, Meis PJ, et al. 2002. The preterm prediction study: elevated cervical ferritin levels at 22 to 24 weeks of gestation are associated with spontaneous preterm delivery in asymptomatic women. Am J Obstet Gynecol 186: 458-63.

11. Scholl TO. 1998. High third dimension ferritin concentration: association with very preterm delivery, infection, and maternal nutritional status. Obstet Gynecol 92: 161- 6.

12. Hillier SL, Maritius J, Krohn MJ. 1988. A case control study of chorioanmnionic infection and histologic chorioamnionitis in prematurity. $N$ Engl J Med 319: 972-8.

13. Gibbs RS, Romero MD, Hillier SL, Eschenbach DA, Sweet RL. 1992. A review of premature birth and subclinical infection. Am J Obstet Gynecol 166: 1515-28.

14. Norman K, Pattinson RC, de Souza J, de Jong P, Moller G, Kirsten G. 1994. Ampicillin and metronidazole treatment in preterm labour: a multicentre, randomised controlled trial. $\mathrm{Br} \mathrm{J}$ Obstet Gynaecol 101: 404-8.

15. Tamura T, Goldenberg RL, Johnston KE, Cliver SP, Hickey CA. 1996. Serum ferritin: a predictor of early spontaneous preterm delivery. Obstet Gynecol. 